\title{
TÜRKIYE'DE VE AVRUPA TOPLULUĞU'NDA MARKALARIN KORUNMASI
}

\section{Kaan DERicioĞLU*}

\section{TANIM}

Bir işletmenin mal ve hizmetlerini bir başka işletmenin mal ve hizmetlerinden ayırt eden, kişi adları dahil özellikle sözcükler, şekiller, harfler, sayılar, malların biçimi veya ambalajları gibi işaretler marka olarak kabul edilmektedir.

Üretilen veya satışa çıkarılan her türlü malı ayırt etmek için kullanılan işaretler Ticaret Markası (Trade Mark) ve sunulan hizmetleri ayııt etmek için kullanılan markalar Hizmet Markası (Service Mark) olarak tanımlanmaktadır.

\section{TARIHÇE}

Türkiye'de markaların korunması ile ilgili ilk mevzuat 20 Temmuz 1871 tarihli Alameti Farika Nizamnamesi'dir. Bu Nizamnamede sistem, "incelemesiz tescil sistemi" iken 20 Mayıs 1955 tarih ve 6591 sayılı Ek Kanun ile incelemeli sistem'e geçilmiştir. Genel içeriği itibariyle önceki sistemden farklı olmayan, 551 sayılı Markalar Kanunu, 12 Mart 1965 tarihinde yürürlüğe girmiş̧ir. Başvuruların yayınlanması, üçüncü kişilerin başvurulara itiraz yapabilmesi, hizmet markalarının korunması, yenileme süresi gibi çağdaş hükümleri içermeyen bu Kanun, 27 Haziran 1995 tarihinde yenilenmiştir.

\section{YENI MARKA SISTEMI}

Türkiye'de uygulanan yeni marka sisteminde; marka başvuruları ön incelemeden sonra Marka Bülteni'nde yayınlanarak üç ay süreyle itirazlara açık tutulmaktadır. Önceki hak sahipleri, kendi markaları ile aynı veya benzer olan markalara ve aynı veya benzer mal veya hizmetler için başvuru yapılmış ise, itiraz ederek başvurunun reddini talep edebilmektedir. 
27 Haziran 1995 tarihinde yürürlüğe giren 556 sayılı Markaların Korunması Hakkında Kanun Hükmünde Kararname'ye göre, Ticaret Markası ve Hizmet Markası koruması, Türk Patent Enstitüsü’ne yapılacak, ayrı ayrı başvurular ile sağlanmaktadır.

Marka tescilleri sırasında en önemli konu, markanın seçimi ile marka tescilinin kapsayacağı malların ya da hizmetlerin saptanmasıdır. Seçilecek markanın, başkaları tarafından daha önce tescil ettirilmiş ya da fiilen kullanılan markalardan ayıt edilebilecek şekilde farkı ılması gerekmektedir.

Marka tescilleri ile sağlanan koruma, tescil edilecek marka ve markanın kullanılacağı mallar ile sınırlı olduğu için, mal listesi hazırlanırken, gerçek iş konusuna uygun olarak hazırlanmalıdır. Markanın tescil tarihinden itibaren, beş yıl içinde mal listesinde yazılı mallarda kullanılması zorunlu olduğu ve markanın bu süre içinde kullanılmadığı mal için, ilgilli bir kişinin isteği üzerine mahkemece iptal edilebileceği de, bu aşamada, değerlendirilmelidir.

Mallar (Ürünler, Eşyalar) ya da hizmetler için kullanılacak markaların tescil başvuruları Türk Patent Enstitüsü’ne yapılmaktadır. Bu Enstitü'de yaklaşık iki ay kadar süren ön incelemeden sonra, uygun olanlar Marka Bülteni'nde yayınlanarak, üç ay süreyle üçüncü kişilerin itirazlarına açık tutulmaktadır. Markanın tescil edilip edilmeyeceğine itiraz süresi dolduktan sonra karar verilmektedir.

Marka tescillerinde, markanın tescil edileceği mallarda ya da hizmetlerde bir sınırlandırma söz konusu değildir. Ancak, Nis Sını́landırma Anlaşması'ndaki üç sınıftan sonraki her sınıf için, ek ücret ödenmesi gerekmektedir. Örneğin; Sınıf 23: Iplikler; Sınıf 24: Kumaşlar; Sınıf 25: Giyim Eşyaları, üç sınıftır. Bu listeye "Sınıf 2: Kumaş Boyaları" eklendiği zaman, ek ücret ödenmesi gerekecektir. (Türk Patent Enstitüsü, her ek sınıf için bu ücreti 5.000 .000 TL. olarak tesbit etmiştir)

Kanun Hükmünde Kararname ile Hizmet Markaları ilk kez marka tescili kapsamına alınmıştır. Bankacılık, iş yönetimi, taşımacılık, seyahat acentalığı, turizm işletmeciliği, sigortacılık, muhasebecilik, v.b. hizmet sektörlerinde kullanılan markalar da, tescil edilebilecektir. Yeni düzenlemede, 27 Haziran 1995 tarihinden önce fillen hizmet markası kullananların tescil başvuruları için oniki aylık bir geçiş süresi tanınmıştır. Daha önce fiilen hizmet markası kullananların tescil başvuruları, markanın kullanıldığını kanıtlayacak belgeler ile birlikłe, 27 Haziran 1996 tarihine kadar yapılacaktır. Oniki aylık bekleme süresinin bitiş tarihi olan 27 Haziran 1996 tarihinden sonra, bütün başvurular Türk Patent Enstitüsü tarafından değerlendirilecektir. Yapılacak değerlendirmede söz konusu markaların ilk kullanılış tarihleri dikkate alınacak ve aynı hizmet markasının, aynı ya da benzer hizmet alanında birden çok tescil başvurusu söz konusu olduğunda, fiilî kullanım tarihi daha önce olan başvuru tescil için kabul edilecektir. 
Hizmet markası kullanmaya yeni başlayacaklar, belirledikleri hizmet markası ve hizmet alanı için normal bir marka başvurusu yapacaklardır. Bu başvurular, başvuru tarihi esas alınarak değerlendirilecektir. Ancak, bütün hizmet markası başvuruları 27 Haziran 1996 tarihine kadar bekletilecektir.

\section{HIZMET MARKASI TESCILI}

556 sayılı Kanun Hükmünde Kararname ile Hizmet Markaları da, marka tescili kapsamına alınmışıı. Yeni düzenlemeye göre; bankacııı, iş yönetimi, taşımacılık, seyahat acentalığı, turizm işletmeciliği, sigortacıllk, muhasebecilik, v.b. hizmet sektörlerinde kullanilan markalar da, tescil edilebilecektir.

27 Haziran 1995 tarihinden önce fiilen hizmel markası kullananların tescil başvuruları ıçin oniki aylık bir geçiş süresi tanınmıştır. Daha önce fiilen hizmet markası kullananların tescil başvuruları, markanın kullanııdığını kanıtlayacak belgeler ile birlikte, 27 Haziran 1996 tarihine kadar, yapılacaktır. Oniki aylık bekleme süresinin bitiş tarihi olan 27 Haziran 1996 tarihinden sonra, bütün başvurular Türk Patent Enstitüsü tarafından değerlendirilecektir. Yapılacak değerlendirmede söz konusu markaların ilk kullanılış tarihleri dikkate alınacak ve aynı hizmet markasının, aynı veya benzer hizmet alanında birden çok tescil başvurusu söz konusu olduğunda, fiilî kullanım tarihi daha önce olan marka tescil edilecektir.

\section{KULLANMA ZORUNLULUĞU}

Tescilli markanın, tescil tarihinden itibaren beş yıl içinde kullanılması zorunludur. Bu süre içinde kullanımayan markalar, aynı markayı kullanmak isteyen bir başka kişinin talebi üzerine mahkeme tarafından iptal edilebilir.

\section{KORUMA SÜRESI VE YENILEME}

Markanın koruma süresi, başvuru tarihinden itibaren on yıldır. Bu süre her on yılda bir yenilenebilir. Yenileme için, koruma süresinin bitiş tarihinden önceki altı ay içinde, başvuru yapmak gerekir. Koruma süresinin bitiş tarihinden sonraki altı ay içinde markanın yenileme başvurusu yapılması halinde, yenileme ücretinin \% 50 cezalı ödenmesi gerekecektir.

\section{MARKA KORUMASININ ÜLKE SINIRLARI}

Türkiye'de yapılan bir marka tescili, yalnız Türkiye sınırları içinde koruma sağlar. Markanın diğer ülkelerde de korunması için, o ülkelerde de tescil ettirilmesi gerekir. 


\section{PARIS SÖZLEŞMESI VE RŪÇHAN HAKKI}

Sınaî Hakların Korunması için Paris Sözleşmesi hükümlerine göre, Türkiye'de bir markanın tescili için yapılan başvuru tarihinden itibaren altı ay içinde, bu sözleşme üyesi bir başka ülkeye yapılacak başvuru sırasında rüçhan hakkı talep edilebilir. Bu durumda, Türkiye'deki başvuru tarihi ile diğer ülkeye yapılan başvuru tarihi arasında, aynı markanın tescili için başkaları tarafından yapılacak başvurular ile başkaları adına yapılacak marka tescillerinin hükümsüz sayılması sağlanabilir. Rüçhan hakkının elde edilmesi için Türkiye'de bir başvuru yapılması yeterlidir. Markanın Türkiye'de tescili bu işlem için önemli değildir. Altı aylık rüçhan hakkı süresi geçirildikten sonra, yurt dışında yapılan marka tescil başvuruları, başvuru tarihi dikkate alınarak değerlendirilir.

\section{AVRUPA TOPLULUK MARKASI TESCILI}

Avrupa Birliği ülkelerinin tamamı için geçerli olan, Topluluk Markası tescili 1 Nisan 1996 tarihinden itibaren başlamıştır. Başvurular, İspanya'nın Alicante şehrinde kurulan "lç Pazarda Uyum Sağlama Ofisi"ne (OHIM) ya da bütün Topluluk Marka Ofisleri'ne yapılabilecektir. Tescil ile ilgili değerlendirme OHIM'e yapılacaktır.

Türkiye, Paris Sözleşmesi ve Dünya Ticaret Örgütü Kuruluş Anlaşması üyesi olduğu için, Türk vatandaşları da bu olanaktan yararlanabilecektir. Topluluk markası tescili, işlem olarak bir zorunluluk değildir. Topluluk markası olarak yapılacak bir tek tescil ile topluluğun ülkeleri olan Avusturya, Ingiltere, Danimarka, Almanya, Finlandiya, Fransa, Yunanistan, İrlanda, İtalya, Belçika, Lüksemburg, Hollanda, Portekiz, Ispanya ve Isveç'te, markanın korunması sağlanacaktır.

Topluluk markası için yapılacak başvurular yayınlanarak üye ülkelerin itirazlarına açılacak ve 15 ülkeden hiç birinin itiraz etmemesi halinde, tescil işlemi yapılacaktır.

Topluluk üyesi ülkelerden herhangi birinin itiraz etmesi halinde, Topluluk Marka Tescili isteği reddedilecektir. Bu durumda, itiraz etmeyen ülkelere tek tek başvurarak ulusal marka tescillerinin yaptırıması ile, marka tescil ihtiyacı karşılanabilecektir.

Avrupa Birliği ülkelerinden herhangi birinde markaları tescilli olan Türk vatandaşları, Topluluk markası tescilini talep ederken veya itiraz aşamasında, bu ülkelerdeki mevcut tescillerinin kıdemini (seniority) talep edebileceklerdir.

Topluluk markası tescili masraflarının, itiraz işlemleri hariç, yaklaşık 5000 ila 7500 US\$ arasında tutacağı tahmin edilmektedir. 15 ülkede ayrı ayrı yapılacak tescilin maliyetinin 30000 ila 45000 US\$ arasında olduğu düşünülürse, Topluluk Marka Tescili maliyet açısından avantaj sağlamaktadır. 
Topluluk markasının koruma süresi on yıldır. İstek halinde her on yılda bir yenilenebilir. Topluluk markasının tescilden itibaren beş yıl içinde kullanılması zorunludur. Bu durum markanın mahkemece iptali için gerekçe kabul edilecektir.

Topluluk Markası Tescili ile sağlanacak diğer avantajlar aşağıda özetlenmiştir :

- Tescil ve yenilemede daha düşük masral (15 ülke yerine tek bir başvuru, işlem ve yenileme),

- OHIM'de inceleme olmaması, yalnız üçüncü kişilerin itirazının söz konusu olması,

- Daha az kullanım gereği. Topluluk markasının Avrupa Birliği ülkelerinin tümü yerine bazılarında kullanımının yeterli olması,

- Tek bir işlem ile Avrupa Birliği'nde markaya tecavüz olaylarının kovuşturulması.

Topluluk Markası Tescilinin dezavantajları şunlardır :

- Marka tüm Avrupa Birliği ülkelerinde tescil edilemiyorsa, Topluluk Markası tescil edilememesi,

- Tek bir itiraz veya iptal veya hükümsüzlük talebi ile marka başvurusu veya tesciline karşı işlem yapılabilmesi,

- Topluluk Markasının birlik ülkelerinden biri için devir edilememesi. 